\title{
Economic prerequisites for the development of low-energy based on the development of unclaimed hydrocarbon deposits
}

\author{
E S Melekhin ${ }^{1, *}$, A A Pelmeneva ${ }^{1}$ and $E S$ Kuzina $^{2}$ \\ ${ }^{1}$ FGAOU IN VGU of oil and gas (NRU) them. I.M. Gubkina, Department of Economics of the Oil and Gas Industry, 65, Leninsky \\ Avenue, Moscow, 119991, Russia \\ ${ }^{2}$ Moscow branch of Gazprom Design Engineering, Vernadskogo Avenue, 41c1, Moscow, 119415, Russia
}

\begin{abstract}
The article assesses the state of the mineral resource base of hydrocarbon raw materials, provides estimates of the commercial efficiency of hydrocarbon field development, examines and substantiates the main economic prerequisites for the development of distributed generation based on the development of unclaimed small hydrocarbon fields.
\end{abstract}

\section{Introduction}

In modern conditions, both in the world and in Russia, there is a depletion and deterioration of the mineral and raw material base of fuel and energy resources [1]. In recent years, the growth of oil reserves, condensate and free natural gas in Russia is practically nonexistent with an insignificant (by $0.5 \%$ ) increase in their share in the distributed subsoil fund (Table 1).

At the same time, for all types of hydrocarbons there is an increase in production volumes (Table 2). In the distributed subsoil fund there has been an increase in the number of subsoil plots, including hard-to-recover and unprofitable reserves of oil and natural gas [2]. Exhausted gas fields increasingly contain the so-called low-pressure gas.

In the unallocated subsoil fund, the number of unclaimed subsoil plots containing small and medium hydrocarbon reserves is constantly increasing and amounts to more than 1500 units [3]. The streamlining of the structure of the mineral resource base of fuel and energy resources should be based on rational use of mineral resources, which should be based on economic incentives for its development [4].

\section{Economic prerequisites for the development of unclaimed hydrocarbon deposits}

The development of small hydrocarbon deposits located in close proximity to human settlements may be attractive for both the investor and the municipality of the Russian Federation [5]. Any investment project is implemented to make a profit. At the same time, the implementation of an investment project (IP) should be beneficial both to the investor and to the region (municipality of the Russian Federation) where this enterprise is located [6].
We will evaluate economic efficiency of developing a small oil field and using produced oil for refining at a mini-refinery (small refinery). An oil refining plant can be located on a land plot of 2400 square meters (for the production output of 200-250 thousand tons per year).

Mini refineries have the following advantages:

- maximum process optimization leading to lower operational and capital expenditures;

- small dimensions of raw materials processing plants facilitate their transportation, reduce installation costs, and also make it possible to adjust the technological parameters of the plant with uncomplicated maintenance of all devices;

- for efficient production no water, steam or other additional resources are required;

- full compliance with fire safety and labor protection standards.

According to the manufacturer of the mini-refinery, total output from the materials consists of: gasoline $22 \%$; diesel fuel 30\%; fuel oil 45\%; hydrocarbon gas 3\% [7]. In the processing of raw materials, there are also losses that, with the efficient equipment use, do not exceed $2 \%$ [8].

A small oil field with recoverable reserves of $\mathrm{C} 1$ category - 1 million tons - and an average depth of fluids of 3,500 meters was taken as the base of calculations. Based on the estimated volume of recoverable oil reserves, the average annual production will be 0.4 million tons. The estimated life of the field with a $\mathrm{CIN}=0.5$ will be 13 years.

The calculation of the commercial efficiency of the development of a subsoil plot was made on the basis of data on an analogous object with their adjustment to the existing conditions of operation of the object. The calculation of capital investments in the field development is summarized in table 3 .

Total capital expenditures amount to 1212.0 million rubles, including capital investments in the field

* Corresponding author: esmelekhin@yandex.ru 
Table 1. The state of the mineral resource base of hydrocarbons.

\begin{tabular}{|c|c|c|c|c|}
\hline \multirow[t]{2}{*}{ Hydrocarbon reserves and resources } & \multicolumn{3}{|c|}{ Period } & \multirow{2}{*}{$\begin{array}{c}\text { Trend of change } \\
(2017 / 2015),+,-,(\%) \\
\end{array}$} \\
\hline & 2015 & 2016 & 2017 & \\
\hline \multicolumn{5}{|l|}{ Category Stocks } \\
\hline $\mathrm{A}+\mathrm{B}+\mathrm{C1}$ & & & & \\
\hline Oil, million tons & 18435.4 & 18488.9 & 18496.6 & $61.2(100.3)$ \\
\hline Condensate, million tons & 2314.2 & 2310.1 & 2353.3 & $39.1(101.7)$ \\
\hline Free gas, trl. $\mathrm{m}^{3}$ & 50.7 & 50.5 & 49.5 & $-1.2(97.6)$ \\
\hline Dissolved gas, trl. $\mathrm{m}^{3}$ & 1418.2 & 1411.2 & 1463.0 & $44.8(103.2)$ \\
\hline \multicolumn{5}{|l|}{$\begin{array}{l}\text { The share of the distributed subsoil } \\
\text { fund, } \%\end{array}$} \\
\hline Oil & 96.2 & 96.5 & 96.2 & $(0.0)$ \\
\hline Condensate & 97.7 & 98.2 & 98.4 & $(0.7)$ \\
\hline Free gas & 96.3 & 96.8 & 97.4 & (1.1) \\
\hline Dissolved gas & 94.6 & 94.9 & 95.0 & $(0.4)$ \\
\hline \multicolumn{5}{|l|}{$\mathrm{B} 2+\mathrm{C} 2$} \\
\hline Oil, million tons & 11221.8 & 11187.1 & 11326.0 & $104.2(100.9)$ \\
\hline Condensate, million tons & 1270.1 & 1228.4 & 1695.9 & $425.8(133.5)$ \\
\hline Free gas, trl. $\mathrm{m}^{3}$ & 19.3 & 18.7 & 23.8 & $4.5(123.3)$ \\
\hline Dissolved gas, trl. $\mathrm{m}^{3}$ & 1483.2 & 1491.2 & 1501.1 & $17.9(101.2)$ \\
\hline \multicolumn{5}{|l|}{$\begin{array}{l}\text { The share of the distributed subsoil } \\
\text { fund, } \%\end{array}$} \\
\hline Oil & 90.0 & 91.2 & 94.1 & $(4.1)$ \\
\hline Condensate & 94.7 & 94.9 & 94.6 & $(-0.1)$ \\
\hline Free gas & 92.9 & 94.9 & 95.0 & $(2.1)$ \\
\hline Dissolved gas & 90.9 & 92.0 & 92.2 & (1.3) \\
\hline
\end{tabular}

Table 2. Extraction of fuel and energy resources.

\begin{tabular}{|l|c|c|c|c|}
\hline \multicolumn{1}{|c|}{ Hydrocarbon production } & \multicolumn{3}{|c|}{ Period } & $\begin{array}{c}\text { Trend of change } \\
(2017 / 2015), \%\end{array}$ \\
\hline & 2015 & 2016 & 2017 & \\
\hline Oil, million tons & 508.7 & 513.0 & 512.9 & 100.8 \\
\hline Condensate, million tons & 25.3 & 27.5 & 27.4 & 108.3 \\
\hline Free gas, trl. $\mathrm{m}^{3}$ & 592.6 & 595.4 & 645.1 & 108.9 \\
\hline Dissolved gas, trl. ${ }^{3}$ & 44.7 & 47.2 & 46.7 & 104.5 \\
\hline Compiled by the authors according to [1,2].
\end{tabular}

Table 3. Capital investment in field development, mln. rub.

\begin{tabular}{|c|c|c|c|c|c|}
\hline \multicolumn{2}{|c|}{ Production drilling } & \multirow{2}{*}{$\begin{array}{l}\text { Commercial } \\
\text { arrangement }\end{array}$} & \multirow{2}{*}{$\begin{array}{l}\text { Environmental } \\
\text { protection }\end{array}$} & \multirow{2}{*}{$\begin{array}{l}\text { Equipment not included in } \\
\text { construction cost estimate }\end{array}$} & \multirow{2}{*}{$\begin{array}{l}\text { Total } \\
\text { capex }\end{array}$} \\
\hline Number of wells & $\begin{array}{c}\text { Capital } \\
\text { investment }\end{array}$ & & & & \\
\hline 3 & 304.5 & 225.3 & 54.2 & 6.0 & 590.0 \\
\hline
\end{tabular}

Table 4. Extended average operating costs for oil production.

\begin{tabular}{|l|c|}
\hline \multicolumn{1}{|c|}{ Expenses } & Value \\
\hline Average operating costs for oil production, RUB/t & 3600 \\
\hline Oil transportation costs, RUB/t & 480 \\
\hline Costs of operation and maintenance of oil pipelines thousand RUB/year & 15000 \\
\hline
\end{tabular}

development - 590.0 million rubles; road construction 450.0 million rubles. According to the price lists of the manufacturers, the average price of a mini-refinery to produce for the production volume specified above will be about 172 million rubles.
The calculation of the average annual operating costs for oil production is made on the basis of the data on the analogous enterprise (table 4).

Average annual operating costs for oil production amount to 179 million rubles. Additional average annual operating costs associated with the operation of a mini- 
refinery will amount to 4199.8 thousand rubles per year, including:

- salary - 3096 thousand rubles. (6 people with an average monthly salary of 43 thousand rubles.);

- contributions to funds $(30 \%)-928.8$ thousand rubles.;

- material costs - 155.0 thousand rubles.;

- other expenses -20.0 thousand rubles.

The estimated output of the mini-refinery by product is: gasoline 110 thousand tons; diesel fuel 150 thousand tons; fuel oil 225 thousand tons; hydrocarbon gas is consumed for process needs. In modern conditions, the average wholesale sales prices are taken at the level of: AI-92 gasoline - $41.800 \mathrm{rub} / \mathrm{t}$; diesel fuel $-35.400 \mathrm{rub} / \mathrm{t}$; fuel oil M-100 - $8700 \mathrm{rub} / \mathrm{t}$.

The calculation of the economic efficiency of the development of the hydrocarbon subsoil area during oil refining at the production site is presented in table 5 .

The release of products is organized directly from the warehouse of the plant. For the storage of gasoline and other combustible materials metal barrels of different volume or cargo tank trucks can be used.

Thus, when refining oil at the production site by reducing the cost of transport infrastructure, a sharp increase in the commercial efficiency of the project is achieved.

\section{Practical use and prospects for the development of small energy based on the development of small hydrocarbon deposits}

The situation is similar to the one in gas production, where about $85 \%$ of new gas fields are small [9]. Therefore, it is worth paying attention to the development of small gas fields and to the geological assessment of mining capabilities of small fields in individual gas accumulation zones $[10,11]$. Gas reserves in small fields can provide annual production of up to 14 billion $\mathrm{m} 3$.

Special attention should be paid to unconventional gas resources, such as coal seam methane, which is widespread in poorly gasified regions of Siberia [12]. Metallic coal gas can be used to produce LNG and/or electricity. We will consider the experience of power generation on the example of the Taldinsky metanoplevol deposit in the Kemerovo region, taking into account that the existing field for its trial operation is already connected to the power system of the Kemerovo region. The economic efficiency assessment was carried out for two separate business processes - gas production (taking into account the sale of the entire volume of produced gas minus the electricity used for

Table 5. A variant of the calculation of the economic efficiency of the development of a subsoil plot during the processing of oil in the place of its production at a mini-refinery.

\begin{tabular}{|l|c|}
\hline \multicolumn{1}{|c|}{ Indicators } & Value \\
\hline 1. Total capex, mln. rub. & 1212.0 \\
\hline 2. Proceeds from sales of products, total, mln. rub. & 11883.5 \\
\hline gasoline grade AI-92 & 4598.0 \\
\hline diesel fuel & 5310.0 \\
\hline fuel oil fuel M-100 & 1975.5 \\
\hline 3. Operating costs, including taxes, total, mln. Rub. & 2381.6 \\
\hline including mini-MPZ & 54.6 \\
\hline 4. Balance profit, mln. rub. & 9501.9 \\
\hline 5. Property tax, mln. rub. & 26.7 \\
\hline 6. Income tax, mln. rub. & 1895.0 \\
\hline 7. Net profit, mln. rub. & 7580.2 \\
\hline 8. Average annual net profit, mln. rub. & 583.0 \\
\hline 9. Payback period of capital investments, years & 2.1 \\
\hline 10. Net present value, mln. rub. & 4927.4 \\
\hline 11. Discounted payback period of capex, years & 3.2 \\
\hline
\end{tabular}

Table 6. The main indicators of the economic efficiency of the implementation of investments in the production of electricity.

\begin{tabular}{|l|c|c|}
\hline \multicolumn{1}{|c|}{ Cost effectiveness indicators } & $\begin{array}{c}\text { Gas production and sale } \\
\text { (pilot development, 20 } \\
\text { production wells) }\end{array}$ & $\begin{array}{c}\text { Generation and sale of } \\
\text { electrical and thermal energy } \\
\text { (construction of HPP) }\end{array}$ \\
\hline $\begin{array}{l}\text { Accumulated net cash flow (net income) (NI), mln } \\
\text { rub. }\end{array}$ & 1286.99 & 2706.10 \\
\hline Net present value (NPV), mln rub. & 20.56 & 692.80 \\
\hline Internal rate of return (profitability) (IRR), \% & 10.32 & 21.61 \\
\hline Undiscounted payback period (PP), years & 8.80 & 5.9 \\
\hline Discounted payback period (DPP), years & 17.00 & 7.6 \\
\hline Capital investment return index (CI), unit shares & 1.02 & 1.74 \\
\hline Maximum negative cash (MNC), mln rub. & -955.21 & -835.60 \\
\hline
\end{tabular}


electricity generation for own needs of the field), as well as the production and sale of electric and thermal energy at 12.25 MW gas piston power plants (GPPP) (including the cost of gas used as fuel in the project operating costs). Comprehensive assessment of the effectiveness of investments in the extraction of methane and its use at GEPP are presented in Table 6.

The cost price of electricity generation at GPPs is 2.1 $\mathrm{rub} / \mathrm{kWh}$, the price for accepting them to the power system of the Kemerovo Region is $3.6 \mathrm{rub} / \mathrm{kWh}$, with an average selling price of electricity for enterprises 2.7 $\mathrm{rub} / \mathrm{kWh}$ and the population $1.8 \mathrm{rub} / \mathrm{kWh}$. Overestimation of the price of acceptance significantly reduces the profitability of HPPs. Therefore, it is necessary to work on optimizing the pricing of electricity in the Kemerovo region.

Risk analysis revealed the factors that have the strongest impact on the effectiveness of investment in the project $[13,14,15]$. These factors are the volume of gas production, the selling price of electricity and the volume of capital investments in the project. On the one hand, a negative change in these factors relative to project values will lead to a decrease in project profitability; on the other hand, effective management of these economic parameters, from the point of view of project economics, will significantly increase the economic performance of the Taldinsky coal deposit, and other similar enterprises operating at small deposits.

\section{Conclusion}

The development of small hydrocarbon deposits in the region will significantly improve the performance of the fuel and energy balance of a constituent entity of the Russian Federation, meaning the ratio between the income and consumption of fuel and energy resources, their sources of income and their uses.

Thus, the development of small hydrocarbon deposits, in addition to improving the efficiency of investing in the search, evaluation and exploration of fuel and energy resources in general, makes it possible to effectively develop small energy in the raw materials regions of the Russian Federation, which, in turn, will contribute to their socio-economic development.

The trends in the development of small energy based on the development of unclaimed hydrocarbon deposits can be recommended for use in the raw material-oriented regions of the Russian Federation to assess the prospects for the development of small energy there.

\section{References}

1. State report "On the state and use of the mineral resource base of the Russian Federation in 2015", 341 (2017)

2. State report "On the state and use of the mineral resource base of the Russian Federation in 2016 and 2017", 370 (2017)

3. E.S. Melekhin, Economic aspects of the formation of a rational use of mineral resources in modern conditions [Electronic resource]: monograph E.S. Melekhin, ISBN978-5-91961-308-4 (2018)

4. E.S. Melekhin, G.Z. Omarov, On economic incentives for rational subsoil use, Mineral resources of Russia. Economics and Management, 1, 44-47 (2018)

5. A.L. Novoselov, S.V. Staroverov, The use of small gas fields for the development of small distributed energy in Russia, Mineral resources of Russia. Economics and Management, 2, 51-53 (2013)

6. A.L. Novoselov, S.V. Staroverov, The economic rationale for the use of unclaimed gas fields for energy supply of settlements, Economics of Nature Management, 4, 17-23 (2013)

7. G.C Watkins, Oil scarcity: What have the past three decades revealed?, Energy Policy, 34(5), 508-514 (2006) DOI: 10.1016/j.enpol.2005.11.006.

8. M. Lynch, Forecasting oil supply: theory and practice, The Quarterly Review of Economic and Finance, 42, 373-389 (2002)

9. M.B. Skvortsov, V.D. Nemova, M.V. Dakhnova, E.A. Kopilevich, N.D. Surova, A.M. Kirsanov, S.V. Mozhegova, New methodological approaches to the assessment of oil resources in the sediments of the Bazhenov formation, Geology and Geophysics, 2, 209-216 (2019)

10. I.V. Scarf, Financial and organizational aspects of the reproduction of the hydrocarbon resource base in a regional context, Economy of the region, 13(2), 628-640 (2017)

11. D. B. Reynolds, Using non-time series to determine supply elasticity: How far do prices change the Hubbert curve?, OPEC Re, 6, 147-167 (2002)

12. A.L. Novoselov, I.Yu. Novoselova, I.M. Potravny, Model of development of mineral resources in the region based on the principles of "green" economy, Mining Journal, 7, 55-58 (2017)

13. A. Novoselov, I. Novoselova, I. Potravnii, V. Gassiy, Conflicts management in natural resources use and environment protection on the regional level, Journal of Environmental Management and Tourism, 7-3(15), 407-415 (2016)

14. M.S. Gasparian, I.A. Kiseleva, D.G. Korneev, S.A. Lebedev, V.A. Lebedev, Strategic analysis of risks when implementing investment projects, Espacios, 39(27), 16 (2018)

15. L.A. Zadeh, K.S. Fu, K. Tanaka, Fuzzy sets and their applications to cognitive and decision processes, Proceeding of the US- Japan Seminar on Fuzzy Sets and Their Applications, 7, 1-4 (2014) 